Füleki Réka ${ }^{1}$

\title{
A kulturális emlékezet megjelenése a katonai protokollban
}

\section{The Emergence of Cultural Memory in Military Protocol}

\section{Absztrakt}

A kulturális emlékezet szimbólumok, jelek és jelképek azon megjelenése, amely egy nemzet emlékezetét és identitását generációkra meghatározza. A magyar történelemben számos olyan eseményt találhatunk, amelyek nemzedékekre meghatározták a magyarságtudat szimbólumait, jelképeit. A katonák által közvetített szimbólumokon a 20. század során nem csak jelentös, de meglehetösen gyors ütemü, dinamikus változások figyelhetök meg. Az adott korszak politikai berendezkedésének, ideológiai rendszerének a nemzet emlékezetére gyakorolt hatása az állami és a nemzeti ünnepek alkalmával közvetített kulturális értékek szimbolikájára is kiterjedt.

Kulcsszavak: szimbólum, jelkép, kulturális emlékezet, katonai protokoll, nemzeti ünnep, nemzeti identitás

\section{Abstract}

Cultural memory is the appearance of symbols, signs, and emblems that define the memory and identity of a nation for generations. In Hungarian history we can find many events that have defined the symbols of the Hungarian consciousness for generations. Not only significant but rather fast-paced, dynamic changes can be observed on the symbols conveyed by soldiers during the $20^{\text {th }}$ century. The influence of the ideological system of the political system of the given period on the memory of the nation extends to the symbolism of the cultural values conveyed on the occasion of state and national celebrations.

Keywords: symbol, emblem, cultural memory, military protocol, national day, national identity

Nemzeti Közszolgálati Egyetem Hadtudományi Doktori Iskola, doktorandusz - University of Public Service Doctoral School of Military Sciences, PhD student, email: reka.fuleki.91@gmail.com, ORCID: https://orcid.org/0000-0001-7124-3198 


\section{A szimbólumok szerepe a társadalomban}

Az emberi létezés és kultúra egyik fundamentális kifejezőeszközeként tekinthetünk a szimbólumok, jelek és jelképek rendszerére, amelyek akár generációkon át összekötnek egy nemzetet, mivel a metakommunikáció szintjén szemlélve, funkciójuk ellátása során hatással vannak a kulturális és a történelmi emlékezet továbbörökítésére, valamint különböző korszakokban való értelmezésére. Minden nemzet életében a történelmi múlt olyan értékeket őriz, amelyek nemzedékekre meghatározzák a kulturális és nemzeti identitás alapjául szolgáló társadalmi emlékezetet. Ennek egyik eszközéül tekinthetünk a történelem során kialakult szimbólumokra, jelképekre, azok együttes rendszerére, amelyek a nonverbális kommunikáció tárházának mögöttes tartalommal rendelkezö jelentéshordozó elemei.

A belgiumi születésű francia szociológus, etnológus és antropológus, Claude LéviStrauss az alábbi értelmezést nevezi meg a kultúra és a szimbólumok közti kapcsolat viszonyára vonatkozóan: „Minden kultúra felfogható szimbolikus rendszerek együttesének, amelyek közül a legfontosabbak a nyelv, a házassági szabályok, az ökonómiai viszonyok, a múvészet, a tudomány, a vallás. Mindezek a rendszerek a fizikai valóság és a társadalmi valóság bizonyos szempontjainak kifejezésére törekednek, de még inkább a valóság e két típusa között fennálló viszonyoknak, nemkülönben a szimbolikus rendszerek egymás közti viszonyainak a kifejezésére."' $\mathrm{A}$ Lévi-Strauss által megfogalmazott megállapítást alapul véve kijelenthetjük, hogy a szimbólumok a társadalom életében fontos helyet töltenek be, a kommunikáció során jelentéshordozó képességük meghatározó szerepü. Hiszen például egy katonai tiszteletadással megrendezendő eseményen minden felvonuló elem - egyenruha, térhasználat, zászlók stb. - saját, nonverbális nyelvén kommunikál a rendezvény résztvevőivel.

Geert Hofstede, holland szociálpszichológus, a nemzeti és szervezeti kultúrák interakcióinak szakértője a kultúra és az azt meghatározó szimbólumok relációját tekintve megfogalmazta, hogy egy kultúraréteg vizsgálata során a szimbólumokat a rétegek külső burkaként értelmezhetjük. Ezek a szimbólumok meghatároznak speciális jelentéstartalommal rendelkező szavakat, tárgyakat (például zászlók, építészet), gesztusokat (például az igen bólintása), státuszszimbólumokat, amelyek a társadalom formálódása során gyorsan változhatnak. ${ }^{3}$ Hofstede kultúra és szimbólumok kapcsolata közti vonatkozás megállapítására támaszkodva kimondhatjuk, hogy Magyarország történelme a 20. század során nemcsak jelentős, de meglehetősen gyors ütemü, dinamikus változásokon esett át, amely kihatott a nemzet identitására, az alkalmazott szimbólumok rendszerére, valamint a tanulmány fókuszába helyezett katonai haderöre, annak protokolláris feladataira.

A tanulmány fő célja, hogy rávilágítson azokra az eseményekre, elemekre, amelyek alapvető változásokat hoztak a katonai tiszteletadással végrehajtott rendezvények jellegén. A felvillantott kérdéseket, vizsgálati pontokat a későbbiekben önálló tanulmány formájában fogom részletesen kidolgozni. Az elkövetkezőkben röviden ismertetem azokat a nagy erejü változtatással bíró korszakokat, amelyek meghatározzák jelenkori

Claude Lévi-Strauss: Strukturális antropológia. Budapest, Osiris. 2001. I. k. 231.

Geert Hofstede: Culture's Consequences: Comparing Values, Behaviors, Institutions and Organizations Across Nations. Thousand Oaks, CA - London - New Delhi, Sage Publications, 2001. 9-10. 
nemzeti identitásunkat, kulturális emlékezetünket. Külön kitérek a honvédség helyzetére, jelképeinek változásaira, amelyek részben a ruházaton, részben pedig protokolláris eseményeken való szolgálatteljesítés közben jelennek meg.

\section{Kulturális emlékezetünk a 20. században}

A 20. század eseményei, történelmi fordulatai - I. világháború, II. világháború, rendszerváltás - meghatározó szerepet játszottak jelenünk kollektív kulturális és történelmi emlékezetének alakulásában. A 20. századi magyar történelem bővelkedik olyan döntő fontosságú történelmi eseményekben, amelyek nemzedékekre meghatározták a magyarságtudat szimbólumait, jelképeit. Nemzeti identitásunk és emlékezetünk formálódásának vizsgálata során, véleményem szerint, a vizsgált történelmi időszakot (legalább) öt korszakra tagolhatjuk; dualizmus kora, Horthy-korszak, Rákosi-korszak, Kádár-korszak és rendszerváltás.

Egy nemzet kulturális és történelmi emlékezete leginkább az állami és nemzeti ünnepeiben figyelhető meg. A megnevezett korszakok gyors ütemű ideológiai változásának demonstrálása során több ízben kitérek államalapító Szent István királyunk ünnepére, augusztus 20-ra, amely legrégibb magyar ünnepként maga is önálló szimbólummá vált. Az ünnep értelmezése során szigorúan szimbólumrendszerére, eszmei hátterére, valamint a katonai szerepvállalás sajátosságaira szorítkozom. Az eredetileg egyházi, szekularizált ünnep a 20. század során az uralkodó politikai hatalom által közvetített értékeknek megfelelően változásokon, tartalmi megújításon ment keresztül.

Az I. világháború veszteségeit követően Vitéz nagybányai Horthy Miklós kormányzó a trianoni békeszerződés okozta nemzeti traumára építve alapozta meg revizionista ideológiáját, amely szorosan összekötötte a sokféle fájdalmat elszenvedett magyarságot. A trianoni békeszerződést követően az addig elsősorban egyházi ünnep nemzeti tartalommal egészült ki. A területében és népességében is jelentősen megfogyatkozott magyarság számára közös nemzeti cél, a Szent István-i Magyarország visszaállítására való emlékezés jelképpé vált. ${ }^{4} \mathrm{Az}$ ünnep megtartása kibővült tisztavatással, ünnepélyes őrségváltással, a néphagyományok ápolásával. Szimbolikáját tekintve ez a Horthy-korszak revizionista politikája végett még a dualista, OsztrákMagyar Monarchia jelképeiből merítkezik, amely többek között a katonai egyenruha részleteiben is megmutatkozik.

A korszakot meghatározó látásmód nem különítette el a hagyományossá vált díszruha és tábori ruha kettősségét, hanem az újonnan létrejött tömeghadsereg elvárásaihoz mérten úgynevezett „általános rendeltetésü" egyenruhákat vezettek be, amely a mindennapokra vetítve azt jelentette, hogy a gyakorlóruhát próbálták meg úgy átalakítani, hogy az díszelgő és kimenő alkalmakkor is hordható legyen. ${ }^{5}$

A ruházatot tekintve az első szembeszökő változásként a színét emelhetjük ki. Tábori szürkéről tábori barnára változtatták, és magyar vagy magyarosnak vélt öltözetet készítettek. A ruházat különböző elemein a Szent Korona mint jelkép és a kor

Múlt-kor: Szent Istvántól az új kenyérig. 2012.

Ságvári György: Magyar uniformisok a honfoglalástól napjainkig. Budapest, Kossuth, 2010. 172. 
szellemének, követendő eszméjének reprezentatív eszköze több ízben is megjelent, ezzel is erősítve a Szent István szimbolikát, amely a revizionista politika ideológiai eszközévé vált. Az egyenruha leegyszerüsödött, a praktikum játszott szerepet, egyszerre kellett több funkciót - harctéri, kimenő és parádé - ellátnia. A tisztikar számára új díszruházatot rendszeresítettek, amely nem aratott sikert, így 1926-tól újra használatba került az 1918-as atilla. 1931-ben újabb változásokat rendeltek el, mivel az atillák költségesnek bizonyultak, a tisztek társasági zubbonyt kaptak, amelyek az atillák színével voltak megegyezők, valamint azok egyszerüsített díszítőelemeivel voltak ellátva. ${ }^{6}$

Az 1920-as újjászervezés következtében nem csupán az öltözet, de a hadsereg életében elhanyagolhatatlannak számító jelképrendszerben is változások figyelhetők meg. Alkalmazásba került a Magyar Királyság aranyozott kiscímere, amelyet főként a tiszti díszsisakokon helyeztek el, illetve ugyanezt a kiscímert helyezték el a lovasság vállszijas tölténytáskáján is. A Szent Korona hímzett változatának használatát is bevezették - államcímer nélkül ábrázolták, nemzeti színű szalaggal -, főként a szuronyés kardbojtokat ékesítette. A magyar középcímert pedig mint katonai jelképet, 1938-tól vették használatba és föként a csapatzászlókon jelent meg. ${ }^{7}$ Megállapíthatjuk, hogy a Horthy-korszak nem csupán az állami ünnepek tekintetében követte a Szent István korából eredő vagy az államalapító királyunk nyomán létrejött vallási és állami ünnepeket, de a hazához való kötődést a katonaság egyenruháján is tükrözni kívánta, amely eszmét a finom részletekben jelenítette meg, egyben felidézve a nagy Magyarország gondolatát is, amely a kormányzó revíziós politikájának alapját képezte.

A Szent Korona és egyéb koronázási jelvények őrzésével megbízott Koronaőrség egyenruháján az évek előrehaladtával nem figyelhető meg jelentős mértékű változás. Egy, a Magyar Királyi Honvédség részére 1876-ban kiadott öltözeti és fölszerelési szabályzat pontos leírással szolgál a koronaőrök megjelenését illetően a legénységre vonatkozóan, akik "[d]íszben a koronaőr-legénység sastollas sisakkal, nyáron vörös atillában, télen mentében, vörös magyar dísz-nadrágban, barna csizmában (sarkantyú nélkül), rojtos nyakravalóval, bőrkesztyűvel, víbárddal, díszkarddal és fehér derékövvel vonul ki". ${ }^{8}$ Továbbá a tisztekre vonatkozó alaki elvárásokat illetően is részletes leírást kapunk: „Díszben (parade) a koronaőrség tisztjei sastollas sisakkal, nyáron vörös atillában, télen mentében, vörös magyar nadrágban, barna csizmában (sarkantyú nélkül), rojtos nyakravalóval, a gyalogtiszti kardbojttal fölszerelt és a gyalog-tiszti kardkötőn függő diszkarddal és szolgálati derékövvel vonulnak ki és összes érdemjeleiket viselik." 9

A II. világháborúból Magyarország a vesztes oldalon került ki, amely gyökeres változást hozott az ország életébe. A Rákosi-korszak kezdetével és a Szovjetunióval való politikai kapcsolatfelvétel eredményeképpen nemzeti ünnepeink átalakultak, jellegük megváltozott. Azállamalapítás ünnepe, augusztus 20 -a, amely ez idáig kiemelt fontosságú egyházi és állami ünnep volt, háttérbe szorult, 1945-1949 között nem számított állami ünnepnek, valamint 1948-tól az új kenyér ünnepeként jegyezték. 1946-ban

\footnotetext{
Baczoni Tamás: A honvédség egyenruházata és felszerelése. In Holló József Ferenc (szerk.): Hazánk dicsőségére. 160 éves a Magyar Honvédség. Budapest, Zrínyi, 2008. 365-366.

Udovecz György: A magyar államcímer megjelenése a honvédség ruházatán, felszerelésén és technikáján. In Holló József Ferenc (szerk.): Hazánk dicsőségére. 160 éves a Magyar Honvédség. Budapest, Zrínyi, 2008. 357-358.

8 Öltözeti és Fölszerelési Szabályzat a Magyar Kir. Honvédség részére. Budapest, Légrádi Testvérek, 1876. 9.

Öltözeti és Fölszerelési Szabályzat a Magyar Kir. Honvédség részére. (1876) i. m. 10.
} 
elfogadták az új alkotmányt, ezzel kötötték az ünnephez, amelyet a Népköztársaság napjaként jegyeztek be. Ezt követően 1950-től az államalapítás ünnepét törvény szerint ismét állami ünneppé nyilvánították, ám annyi módosítást tettek, hogy nem a sokéves tradíció szerint tartották nyilván. 1989-ig a Népköztársaság Alkotmányának napjaként, az új kenyér ünnepével kiegészülve rendezték meg. Ezekkel a kiegészítésekkel Szent István királyunkról alkotott emlékezetet, történelmi tettei ideológiai jelentőségét igyekeztek elhalványítani. ${ }^{10}$ Ugyanakkor az 1980-as évekbeli ünnepségeken már méltatták (Szent) István király államalapító tevékenységét.

A Jogtörténeti Szemle 2007-es különszámában Horváth Attila fejtette ki, hogy a szovjet típusú államberendezkedés hogyan és milyen mértékben alakította át nem csupán állami ünnepeinket, de a kor ideológiai szemléletét is. A szovjet típusú mintára múködő országok törekedtek arra, hogy jelentőséggel ruházzák fel az általuk meghonosított különféle jeleket és szimbólumokat. Akárcsak a Horthy nevével fémjelzett rendszerben, ezekben az országokban is nyomatékot adtak az ideológiájuknak megfelelő propagandakeltésre és a minél látványosabb, minél impozánsabb külsőségekre. A Rákosi-korszak nem egy újdonsággal szolgált, hiszen egy új időszak köszöntött be, amely magával hozta az egyházi ünnepek fokozatos visszaépítését, valamint a régmúlt ünnepeinek megszüntetését, amely eszmei átalakulás következtében, a szocializmust szimbolizálni hivatott jelképek jegyében új ünnepnapok meghonosítására került sor. A politikában bekövetkező változások nem elhanyagolható újdonsága a munkanapok számának növekedése volt, ${ }^{11}$ amely a lecsökkentett ünnepnapok és átstrukturált nemzeti ünnepeknek volt köszönhetö.12

Az 1956-os forradalom eseményeivel - amelynek kirobbanását a Rákosi-korszak kemény diktatúrájának tulajdonítják -, s annak bukásával egy időben a Rákosi Mátyás által vezetett kormány is elbukott, változásra volt szükség. Hruscsov Kádár Jánost jelölte ki az ország élére. 1957-ben a pártállami irányítás visszatért, a forradalom okozta meggyengült hatalom ismételten való megszilárdítása érdekében diktatórikus eszközöket alkalmaztak.

A történészek, akik Kádár János 33 évének kutatásával foglalkoznak, úgy vélik, hogy a kort nem lehet egységként szemlélni és azonos következtetéseket levonni. Hatalomgyakorlási stílusát tekintve megállapíthatjuk, hogy Kádár János a Rákosi-korszak politikai és intézményrendszerét alkalmazta, viszont úgynevezett puha diktatúrába ágyazta, így az emberek jobban elfogadták azt. A hatalom újbóli megszilárdítása után, az 1960-as évek második felétől a diktatúra fokozatosan enyhült, az 1980-as évekre a rendszeren belüli „liberalizálódás” ment végbe. A Kádár-korszakban megfigyelhető kispolgárosodás nem a nyugati mintára megy végbe, hanem a 20. századi polgárokat vette alapul. ${ }^{13}$ A korszak negatívumait - ügynökök, szellemi elnyomás, ideológia - háttérbe szorították a pozitív változások, hiszen ebben az időben lassan ugyan, de lehetett gyarapodni, a munkanélküliek száma alacsony volt, mivel volt munka.

10 Gyáni Gábor: Relatív történelem. Budapest, Typotex, 2007. 95-97.

11 Az egyházi részvétellel megtartott ünnepek visszaszorításának szándéka mellett, a munkanapok számának növekedését a lerombolt ország háború utáni újjáépítésének feladatával történő indoklások is okolhatták.

12 Horváth Attila: A hatalom ünnepe - az ünnep hatalma. Ünnepek Magyarországon a szovjet típusú diktatúra korában. Jogtörténeti Szemle, (2007), ksz. 42-43.

13 Szegő Iván Miklós: Rendszert vagy korszakot alkotott Kádár János? Origo, 2012. 
A korszakot a katonaság szempontjából vizsgálva az 1956-os események következménye határozta meg. Az 1956-os forradalom és szabadságharc után következett a megtorlási időszak, amely alól a katonaság sem képezett kivételt, így megkezdődött a tisztogatás a lefegyverzett hadsereg állományában. A megbízható haderő érdekében az új hatalomhoz lojális állomány maradhatott meg. Az ennek következtében lecsökkent létszámú hadsereget újraszervezték, amely teljes mértékben alárendeltjévé vált a pártvezetés irányításának..$^{14}$ Ugyanaz a folyamat és stratégia figyelhető meg, amelyet már a Rákosi-rendszerben is megismerhettünk, vagyis az új korszak új és megbízható haderőt igényelt.

A Kádár-korszak ünnepségei elemeit, szerkezeti felépítésüket tekintve nem sokban tértek el a Rákosi Mátyás által megszilárdított ünnepségek forgatókönyvétöl. A periodikusan ismétlődő és szertartásrendhez kötött állami rendezvények sorában az államalapítás ünnepét változatlanul az egyház bevonása nélkül és a Szent Istvánhoz kötődő eszmék elhomályosításával, tényleges jelentéstartalmát elnyomva, az alkotmány napjaként rendezték meg.

A későbbi Kádár-korszakban augusztus 20 -a az alkotmány ünnepe és az új kenyér szentelése mellett további tartalommal bővült, ehhez a naphoz kötődik megannyi épületátadás, a tisztavatások, valamint a légi parádék. Az új ünnepi elemekkel igyekezett a hatalmon levő kormány bizonyítani a nép felé a rendszer pozitív hozadékait.

Fiatal tisztek nyilvános avatási ünnepségéről elöször az 1969. augusztus 21-én megjelent Népszabadság ad tudósítást. A Horthy-korszaktól eltérően a tisztavatás nem az addig megszokott helyszínen zajlott, hanem a Kossuth térre, a parlament épülete elé helyeződött át, amely döntésnek mögöttes tartalma a Magyar Néphadsereg a hazáért tett áldozatkész szerepvállalásának tudatosítása volt az emberekben. A nyilvános avatási ünnep és az ország lobogójának ünnepélyes felvonása, valamint az ezt követő légi parádé és a későbbiekben az esti tűzijáték - amelyeket az ország lakosságának figyelme követett - vélhetően a hadsereg jelentőségének és a katonai hivatásnak az elismerését is szolgálta.

A Kádár-kormány 1957-es hatalomra jutásával nem csupán a Magyar Néphadsereg összetételében, de ruházatában is változások következtek be. A tiszthelyettesek, tisztek és tábornokok egyenruháján már 1957 tavaszán változásokat lehetett megfigyelni, a későbbiekben rendszeresítették a galléron a fegyvernemi szín megjelenítését. 1959-ben a sorállomány ruházatának nagymértékú változtatása kezdődött el, bár ezek az újítások nagyrészt a kimenőruházatot érintették. 1965-ben a zubbonyokon feltüntették a rendfokozati jelzést; a sorállományban szolgáló katonáknak a zubbony gallérjára került rendfokozatuk, míg a hivatásosoké a vállszalagra húzott váll-lapon volt látható. ${ }^{15}$

Az új kormány megalakulása az államcímerre is kihatott. A korábbi Kossuth-címert felváltotta a Magyar Népköztársaság és a Szovjetunió egységét reprezentálni hivatott vörös és piros-fehér-zöld szalaggal átfont búzakoszorúban elhelyezett vágásos címerpajzs, amelynek tetejére vörös csillagot helyeztek. Ez az új címer volt látható a Magyar

\footnotetext{
Kiss Balázs: A Magyar Néphadsereg 1957 - 1990. In Holló József Ferenc (szerk.): Hazánk dicsőségére. 160 éves a Magyar Honvédség. Budapest, Zrínyi, 2008. 157-158.

15 Ságvári (2010) i. m. 212-214.
} 
Néphadsereg valamennyi ruházatán, valamint 1965-töl a díszöveken és tábornoki sapkákon is elhelyezték azokat.

Magyarország történelmében az I. világháború lezárását követően, egészen a rendszerváltásig terjedő időszakig két politikai államberendezkedést és három korszakot határolhatunk körül. A két világháború közötti Horthy-korszak, majd a II. világháború utáni szovjet állami mintára berendezkedett Rákosi- és Kádár-korszak állnak egymással szemben. A Horthy-korszak hagyománytisztelő, nemzeti öntudatra felszólító revíziós politikája kiemelt szerepkört biztosított a katonaságnak.

A trianoni békeszerződés súlyos következményei arra sarkallták a kormányzót, hogy összefogja a magyar népet, ezért Szent István és az államalapítás emléknapját nevezte meg az ország állami ünnepeként. A Magyar Királyi Honvédség protokolláris szolgálatot teljesített az állami és nemzeti ünnepeken. Ruházatuk a dicső múltat idézte. Horthy Miklós politikája a múltidézésre épült, és a revíziót mindenáron megvalósítani akarva vezette az országot. A II. világháború tragikus eseményei és a szovjet Vörös Hadsereg bevonulását követően viszont megváltozott a politika és a katonaság egymáshoz való viszonya.

A Rákosi- és a Kádár-korszakban az államalapítás nem számított nemzeti ünnepnek, így ismételten egyházi lebonyolítással ünnepelték meg, bár sokkal szerényebb ünnepség keretében, mint azt korábban tették. Hazánkban részint a lecsökkent ünnepnapok számának következtében is a katonaság állami ünnepségeken történő protokolláris szerepe is átértékelődött. A honvédekről lekerült a régmúltat idéző atilla, helyette szovjet típusú egyenruhát kaptak, amely a kommunista rendszerhez való tartozás, a Szovjetunióval való baráti kapcsolat tudatosítását szolgálta. Az államalapítás ünnepét felváltotta április 4-e, a felszabadulás napja, és a díszmenetben menetelő katonák az átpolitizált ünnep alkalmával már nem a múltat idézték, hanem az új rendszer iránti lojalitást voltak hivatottak közvetíteni a nép felé.

\section{Nemzeti jelképeink és kulturális emlékezetünk megjelenése a rendszerváltás után}

Magyarország viharos és viszontagságokkal teli történelmében fundamentális jelentőségű az 1989. év, a rendszerváltás éve, amely hazánk történelmének meghatározó periódusát zárta le. A rendszerváltás bekövetkeztével alapvetőleg a magyar állam demokratikus állammá vált. Ennek érdekében szakított a pártállammal, annak kulturális, ideológiai relációival. Ezzel a lépéssel az államszocialista rendszert felszámolták, Magyarország békés úton átalakult egy demokratikus, köztársasági berendezkedésü, európai állammá.

Az időjárási és egyéb katasztrófahelyzetektől eltekintve a polgári társadalom és a honvédség hazánkban hosszú ideje az állami és nemzeti ünnepek rendezvényein érintkezik. Érdemes megfigyelni, hogy a történelem során, az eltérő politikai berendezkedés hatására mennyiben változott, módosult kulturális és történelmi emlékezetünk. Egyes korszakokban előfordult, hogy eltért az ünnepnapok száma, de az sem volt lehetetlen, hogy bizonyos napokra máshogyan emlékeztünk. A protokolláris katonai szerepvállalás jelentéstartalmában is módosulások fedezhetők fel. 
Maga az emlékezés köznapi értelemben nézve az individuum saját tudatában létezik, esetleg egy csoport osztozik a megtörtént események emlékén. Jan Assmann, német származású egyiptológus magyarázata alapján az egyéni, belső megélés egyértelműen nem elegendő az emlékezés meghatározásához és kiterjesztéséhez, kulturális és társadalmi behatások döntik el, milyen hosszan marad fenn a tudatban, milyen eszmék társulnak hozzá. Assmann az emlékezet külső dimenziójának négy területét különbözteti meg - mimetikus emlékezet, ${ }^{16}$ tárgyak emlékezete, kommunikatív emlékezet és kulturális emlékezet ${ }^{17}$-, és ezen belül a kollektív emlékezés ernyője alatt magyarázza el az alapvető különbségeket a kommunikatív és a kulturális emlékezet között. Mind a két fogalom a múlt értelmezésével, annak a jelenre gyakorolt hatásával foglalkozik, ellenben a kettő között rejlő különbség az emlékezés mikéntjében, annak időtartamában és élettartamában jelenik meg. Assmann azt mondja, hogy „[a] kommunikatív emlékezet a közelmúltra vonatkozó emlékeket öleli fel. Olyan emlékekről van szó, amelyekben az ember a kortársaival osztozik."18 Az emlékezés tehát egyéni vagy csoportos szinten valósul meg, élettartama rendszerint egy nemzedékre szorítkozik, ezáltal rövidtávon marad csak fenn, nem válik részévé a hosszú távon elraktározott emlékeinknek, amelyek esetlegesen kanonikus jelleget öltenek. ${ }^{19}$

A kommunikatív emlékezettel szemben, Assmann értelmezése szerint, a kulturális emlékezet sokkal összetettebb folyamat során jön létre, egyfajta fúzióként tekinthető mimetikus emlékezet, tárgyak emlékezete és kommunikatív emlékezet között. Ez a fajta emlékezet a történelem már megszilárdult pontjaira épít, „a múlt itt szimbolikus alakzatokká olvad, ezekbe kapaszkodik az emlékezés". ${ }^{20}$ A kulturális emlékezet számára nem a történelem konkrét eseményei fontosak, hanem az üzenetük, ezáltal nem maga a tényleges esemény válik a társadalom részévé, hanem a mögöttes jelentéstartalom örökíti nemzedékről nemzedékre, és lassan válik mítosszá. Az emlékezés leggyakrabban ünnepek formájában marad fenn, tehát elhatárolódik a mindennapoktól, vagyis ceremoniális jelleget öltve határozza meg egy csoport kollektív identitását. ${ }^{21}$

Magyarország Kormánya, az állami ünnepek mellett kiemel és nemzeti ünneppé nyilvánít három olyan eseményt történelmünkből, amely jeles dátumok meghatározták a magyar gondolkodást és szellemiséget. Periodikus rendezvényként március 15-én megemlékezünk az 1848-49-es forradalom és szabadságharcról, az államalapítás és államalapító Szent István király emlékéről augusztus 20-án, továbbá október 23-án az 1956. évi forradalom és szabadságharc eseményeiről. ${ }^{22}$

Az emlékezésnek megvannak a formai, tárgyiasult eszközei, sajátos hordozói, amelyeket segítségül hívva nemcsak kapcsolatot teremt, de az esemény időtartamára egyesíti is a polgári lakosságot a katonasággal. Ilyen kelléke egy rendezvénynek Magyarország himnusza és a Szózat, a történelmi zászlók, hazánk lobogója, de maga

16 Mimetikus emlékezet definiálása: a szó eredendően utazással kapcsolatos fogalmat jelent, a kultúra területén a megszerzett tapasztalat bizonyos szintủ átvitelére, megőrzésére utal. Jan Assmann: A kulturális emlékezet. Írás, emlékezés és politikai identitás a korai magaskultúrában. Budapest, Atlantisz, 2018. 20.

Assmann (2018) i. m. 19-20.

Assmann (2018) i. m. 51.

Assmann (2018) i. m. 51-53.

Assmann (2018) i. m. 53.

Assmann (2018) i. m. 53-54.

Közigazgatási és lgazságügyi Minisztérium, Társadalmi Kapcsolatokért Felelős Államtitkárság: Nemzeti ünnepek. é. n. 
a 32. Nemzeti Honvéd Díszegység is, amely az emlékezés különböző területeit vizsgálva számos információt közöl a polgári társadalom irányába a kulturális emlékezet felidézése érdekében.

A díszegység szervezetileg a Magyar Honvédség vitéz Szurmay Sándor Budapest Helyőrség Dandárhoz tartozik, rendeltetése szerint három alegységből áll: a Honvéd Koronaőrségből, a Honvéd Palotaőrségből és a Honvéd Díszzászlóaljból. Mindhárom alegységnek megvan a maga rendeltetése és protokolláris feladata a mindennapok során, valamint ünnepi alkalmak esetén díszegységként jelennek meg. Fő feladatuk közé tartozik a Szent Korona örzése, a Sándor-palota örzése és a nemzeti lobogó Kossuth téren katonai tiszteletadással történő fel- és levonása. Ezek csupán azok a feladatok, amelyeket a hétköznapok során láthatunk, ám ennél sokkal átfogóbb munkakörrel rendelkeznek, amelyek megjelennek a mimetikus emlékezet és a tárgyak emlékezete szintjén.

Mimetikus emlékezetnek nevezzük a cselekvésre irányuló viselkedésformát, amely magában foglalja a szokásokat, erkölcsi normákat, vagyis Assmann meghatározása alapján egy átöröklött, elsajátított, tanult forma. ${ }^{23}$ Tehát, ebben a dimenzióban vizsgálva, a 32. Nemzeti Honvéd Díszegység történelmi hagyományoknak, szertartásrendnek megfelelve, a már bevett eljárásrendet követve hajt végre egy-egy katonai tiszteletadással történő eseményt, hiszen a koszorúzás ceremóniája nem változik, bár a díszlépés a 20. századi politikai berendezkedéseknek megfelelő módosulásokon ment át. A szocializmus időszakában - hasonlóan a Varsói Szerződés többi tagországához - a (porosz eredetü) szovjet mintához igazodó díszlépést vette át a honvédség. Majd az 1989-es rendszerváltozás után visszatérés történt az 1945 előtti rendszerben alkalmazott díszlépéshez. A 32. Nemzeti Honvéd Díszegység protokolláris feladatainak ellátásán túl egy különösen nemes feladatot is kapott, amelyet nem mondanak ki valójában egyetlen alkalommal sem, amikor a nyilvánosság előtt szerepelnek. Külön-külön szemlélve az alegységeket, első ránézésre fel sem tünhet a szakavatatlan szemnek, viszont az alegységek legénységeit egységként látva már mindenkinek feltünik a trikolor, amely a ruházati elemeken jelenik meg. Minden alegység saját színnel - piros, fehér és zöld - rendelkezik, Magyarország zászlajának, hazánk egyik jelképének élő reprezentációjaként, amely tudat alatt a nemzeti egységet és összetartozást hivatott erősíteni.

A nemzeti lobogó, az öltözet a tárgyak emlékezete halmazba sorolható elemek, amelyek jellemzően személyes használati tárgyak, amelyeket a mindennapok során veszünk kezünkbe, önmagunkra reflektálnak, és valamilyen szintig a múltat is magukban foglalják, tehát a korábbi időkre is emlékeztethetnek. ${ }^{24}$ Ennek fényében a díszegység, ruházatát tekintve mindenképp múltidéző tárgyi elemnek tekinthető, amelyhez egységes megjelenés és a történelmi hagyományokhoz és gyökerekhez való visszatérés társítható. Mindhárom alegység számára "Tihany" típusú díszegyenruha bakancsos változatát határozták meg. ${ }^{25} \mathrm{Az}$ alegységek feladataiknak megfelelően, a hivatástudat erősítése érdekében egyedi karjelzést és jelmondatot kaptak.

\footnotetext{
Assmann (2018) i. m. 20.

Assmann (2018) i. m. 20.

Honvéd Vezérkar: Vitézséggel és hüséggel! é. n.
} 
A mimetikus emlékezet és a tárgyak emlékezete szintjéröl továbblépve, a megnevezett értelmezéseken túl a díszegység a kulturális emlékezet dimenziójában szemlélve, a koszorúzások, szemlék alkalmával a hagyományt örökítik tovább, már nem a cselekedet, hanem a mögöttes eszme kerül elötérbe. Hasonlóképp a tárgyak emlékezetének dimenziójából példaként kiemelve, a ruházat túllép alaprendeltetésén, nem csupán öltözteti a katonát, de közös múltunk felidézésével üzenetet is közvetít a honvédség szervezetén belül és a polgári társadalom felé is. Úgy tartom, hogy a díszegység újra- és egységgé szervezése mindenképpen nemes dolog, amely az országimázs-épitésben is fontos szerepet játszik, hiszen a legénységet turistafrekventált lokációkon, gyakran látogatott objektumoknál helyezték el, így lehetetlen őket kikerülni egy városnézés alkalmával.

Az assmanni meghatározásokat alapul véve megállapíthatjuk, hogy a múltat igazából megőrizni nem tudjuk. A mindenkori politikai berendezkedés döntő szerepet játszik kulturális emlékezetünk alakulásában, közös nemzeti emlékeink reprezentálásában, amelynek egyik eszköze a 32. Nemzeti Honvéd Díszegység. Az állomány tagjai állami és nemzeti ünnepeinken, katonai tiszteletadással megrendezett hivatalos alkalmak során megjelenésükkel az emlékezés élő eszközeként, az ország múltjának felidézésében vesznek részt. Kulturális örökségünk, nemzeti jelképeink megjelenésében a díszegységnek kiemelt szerepe van, mivel a katonai tiszteletadással megrendezett eseményeken a legtöbb szem rájuk szegeződik.

A rendszerváltozás minden tekintetben megújulást hozott a nemzet életébe. A szovjet típusú diktatúrát követően Magyarország a demokratikus államberendezkedésú országok sorába állt, amely nem csak a politikai ideológiában történő gyökeres változás újrastruktúrálásában nyilvánult meg. Kihatott nemzeti és kulturális emlékezetünkre is, amely megmutatkozik a nemzeti ünnepeink számában és az események jellegében is. A rendszerváltást követően, 1989-től ismét lehetővé vált a Szent Jobb-körmenet egyházi jelenléttel történő megtartása a Szent István-bazilikánál. ${ }^{26}$ Az 1991-es évben az első szabadon választott Országgyülés törvényben emelte hivatalos állami ünneppé államalapító Szent István király napját. ${ }^{27}$ A 2011-ben elfogadott Alaptörvényben külön cikkben nevezik meg a nemzeti ünnepeket, köztük augusztus 20 -át mint az ország hivatalos állami ünnepét.

A rendszerváltozás okán egyfajta identitáskeresés indult meg. Demokratikus állam lévén Magyarország szakított a pártállami berendezkedés eszméivel, hagyományrendszerével. Lehetségessé vált ezáltal a történelmi múltunk emlékeinek ismételt beillesztése a nemzeti és állami ünnepek alkalmaiba. Az említett identitáskeresés érezhető az augusztus 20-i ünnepségsorozat programelemeiben is. Részben fellelhetők a dualista, a Horthy-kor ünnepének egyes alkotórészei, amelyek kiegészülnek a kommunista rendszerben meghonosult szokásokkal, ceremóniákkal. Így maradhatott fenn az 1949-ig új kenyér ünnepének nevezett elem, amely az aratóbálokkal, aratási felvonulással megtartott ünnepet, a "dolgozó parasztságot" helyezte előtérbe. ${ }^{28}$

A katonai feladat-végrehajtás szempontjából szemlélve is szembeszökő változások figyelhetők meg. Minden szovjetes elem - ruházat, díszlépés, jelképek - értelemszerűen

\footnotetext{
Múlt-kor: Hitek és tévhitek Szent István napjával kapcsolatban. 2013.

1991. évi VIII. törvény a Magyar Köztársaság állami ünnepéröl.

Múlt-kor (2012) i. m.
} 
lekerült a palettáról, helyette visszatértünk a korábbi díszlépéshez. A II. világháborúig rendszeresített egyenruhák már csak hagyományőrzés szintjén képviseltetik magukat az ünnepségeken, mivel felváltotta őket a „Tihany” típusú egyenruha, amely egységesíti a díszegység állományát.

Katonai protokolláris feladataikat tekintve, a 32. Nemzeti Honvéd Díszegység állománya rendszeresen „bevetésen van”. A Szent Korona őrzése, a Sándor-palota őrzése és a nemzeti lobogó Kossuth téren katonai tiszteletadással történő fel- és levonása mellett számos egyéb protokolláris feladatot is ellátnak. Részt vesznek a nemzeti ünnepeken és kiemelt fontosságú társadalmi eseményeken, koszorúzásokon. Továbbá kegyeleti feladatokat is teljesítenek, valamint magas rangú külföldi állami és katonai vezetők fogadása is a teljesítendő feladatkörük részét képezi. ${ }^{29}$

Sokrétű feladataikat szemlélve megállapíthatjuk, hogy a díszegység széles spektrumon teljesít szolgálatot. A lakossággal való kapcsolata a kulturális és társadalmi emlékezet életben tartásán, erősítésén túl a nemzeti egység tudatának megszilárdítására szolgál, valamint a kiemelt objektumok protokolláris és biztonsági őrzésével egyfajta biztonságtudatot is keltenek a lakosságban. A hazánkba látogató magas rangú állami és katonai vezetők protokolláris fogadása alkalmával a tiszteletadás mellett nem túlzón, de megjelenik a korábbi korszakokban is ismertetett erődemonstráció képe is.

\section{4. Összegzés}

Kétségtelen, hogy Magyarország történelmének, nemzeti identitásának meghatározó periódusa a 20. század, amely fordulataival és politikai ideológiai változásaival nemzedékekre megalapozta a társadalom kulturális emlékezetét. A múltat természetesen semmissé tenni, kitörölni nem lehet. Magyarország történelmének legnagyobb részében királyság volt, royalista államberendezkedéssel. A 20. század traumatikus fordulatai részben, de nem egészben felülírták a hozzávetőlegesen ezeréves royalista nemzeti identitás kulturális eseményein keresztül végbement beégését.

A Horthy-korszak hagyománytisztelő, nemzeti öntudatra felszólító revíziós politikája kiemelt szerepkört biztosított a katonaságnak. A trianoni békeszerződés súlyos következményei arra sarkallták a kormányzót, hogy összefogja a magyar népet, ezért Szent István és az államalapítás emléknapját nevezte meg az ország állami ünnepeként. A Magyar Királyi Honvédség protokolláris szolgálatot teljesített az állami és nemzeti ünnepeken. Ruházatuk a dicső múltat idézte. Horthy Miklós politikája a múltidézésre és a hagyományápolásra épült, a revízió szem előtt tartásával vezette az országot. A II. világháború tragikus eseményei és a szovjet vörös hadsereg bevonulását követően viszont megváltozott a politika és a katonaság egymáshoz való viszonya.

A Rákosi- és a Kádár-korszakban az államalapítás ugyan nemzeti ünnepeink között volt számon tartva, de a politikai berendezkedés nem engedte a korábban megszokott szertartásrendet. Az ünnepség egyházzal közösen történő lebonyolítása nem volt lehetséges. A II. világháborút követően hazánkban az egyházi szerepvállalással tartott ünnepnapok száma lecsökkent, és a katonaság állami ünnepségeken történő

29 Honvédelem: MH vitéz Szurmay Sándor Budapest Helyörség Dandár. 2012. 
protokolláris szerepe is átértékelődött. A honvédekről lekerült a régmúltat idéző atilla, helyette szovjet típusú egyenruhát kaptak, amely a kommunista rendszerhez való tartozás, a Szovjetunióval való baráti kapcsolat tudatosítását szolgálta. Az államalapítás ünnepét felváltotta április 4-e, a felszabadulás napja, és a díszmenetben menetelő katonák az átpolitizált ünnep alkalmával már nem a múltat idézték, hanem az új rendszer iránti lojalitást voltak hivatottak közvetíteni a nép felé.

A kommunizmus idejében az ünnepnapok forgatókönyvében tulajdonképpen jelentős változás nem figyelhető meg. A berögzült ceremoniális elemek megmaradtak, csupán az adott társadalmi és politikai berendezkedés számára tették elfogadhatóvá. Ennek egyik leggyakrabban alkalmazott eszköze a szovjet himnusz és az internacionálé programba történő beillesztése volt. A katonaság inkább az erődemonstráció kellékéül szolgált, sem mint a korábban megismert nemzeti összetartozást erősítő feladatot ellátó szerv.

Az 1989-es ideológiai változás eredményeképpen a Szent István király nevéhez, az államalapításhoz füződő augusztus 20-i állami és egyházi ünnepeket a régi hagyományok és szokásrendek alapján rendezik meg. Az ünnepségsorozat programjában a régi és a kevésbé régi tradíciók és szokások keverednek, amelyet a 20. század dinamikus változásai, az egyes korszakok nemzeti és történelmi emlékezetbe való beégése eredményez. Az ország, valamint a hadsereg többszöri átszervezése kihatott a nemzeti és szükebb értelemben szemlélve a katonai identitásra is, hiszen a múltat elfelejteni nem lehet. Generációk őrizték meg kulturális emlékezetükben és örökítették tovább a történelem eseményeinek fontosabb momentumait. Ezáltal lehetővé téve a tényleges esemény mögöttes jelentéstartalmának - a társadalom számára az emlékezés révén -, hogy értéket teremtsen. A hagyományok nemzedékről nemzedékre történő átadásával az emlékképekből, történeti tapasztalatokból és élményekből közösségi emlékezet formálódott.

\section{Felhasznált irodalom}

Assmann, Jan: A kulturális emlékezet. Írás, emlékezés és politikai identitás a korai magaskultúrában. Budapest, Atlantisz, 2018.

Baczoni Tamás: A honvédség egyenruházata és felszerelése. In Holló József Ferenc (szerk.): Hazánk dicsőségére. 160 éves a Magyar Honvédség. Budapest, Zrínyi, 2008. 360-374.

Gyáni Gábor: Relatív történelem. Budapest, Typotex, 2007.

Hofstede, Geert: Culture's Consequences: Comparing Values, Behaviors, Institutions and Organizations Across Nations. Thousand Oaks, CA - London - New Delhi, Sage Publications, 2001.

Horváth Attila: A hatalom ünnepe - az ünnep hatalma. Ünnepek Magyarországon a szovjet típusú diktatúra korában. Jogtörténeti Szemle, (2007), ksz. 42-48.

Honvédelem: MH vitéz Szurmay Sándor Budapest Helyőrség Dandár. 2012. Online: https://web.archive.org/web/20150913010709/http://www.honvedelem.hu/ szervezet/Szurmay 
Honvéd Vezérkar: Vitézséggel és hüséggel! é. n. Online: http://2010-2014.kormany. hu/hu/honvedelmi-miniszterium/honved-vezerkar/hirek/vitezseggel-es-huseggel

Kiss Balázs: A Magyar Néphadsereg 1957 - 1990. In Holló József Ferenc (szerk.): Hazánk dicsőségére. 160 éves a Magyar Honvédség. Budapest, Zrínyi, 2008. 157-164.

Közigazgatási és Igazságügyi Minisztérium, Társadalmi Kapcsolatokért Felelős Államtitkárság: Nemzeti ünnepek. é. n. Online: https://2010-2014.kormany.hu/ hu/kozigazgatasi-es-igazsagugyi-miniszterium/tarsadalmi-kapcsolatokert-felelos-allamtitkarsag/felelossegi-teruletek/nemzeti-unnepek

Lévi-Strauss, Claude: Strukturális antropológia. Budapest, Osiris, 2001.

Múlt-kor: Hitek és tévhitek Szent István napjával kapcsolatban. 2013. Online: https:// mult-kor.hu/20130819_hitek_es_tevhitek_szent_istvan_napjaval_kapcsolatban

Múlt-kor: Szent Istvántól az új kenyérig. 2012. Online: https://mult-kor.hu/cikk. php?id=6702

Öltözeti és Fölszerelési Szabályzat a Magyar Kir. Honvédség részére. Budapest, Légrádi Testvérek, 1876.

Szegő Iván Miklós: Rendszert vagy korszakot alkotott Kádár János? Origo, 2012. Online: www.origo.hu/tudomany/20120525-rendszert-vagy-korszakot-alkotott-kadar-janos.html

Ságvári György: Magyar uniformisok a honfoglalástól napjainkig. Budapest, Kossuth, 2010. Udovecz György: A magyar államcímer megjelenése a honvédség ruházatán, felszerelésén és technikáján. In Holló József Ferenc (szerk.): Hazánk dicsőségére. 160 éves a Magyar Honvédség. Budapest, Zrínyi, 2008. 355-359.

\section{Jogi forrás}

1991. évi VIII. törvény a Magyar Köztársaság állami ünnepéröl. Online: https://mkogy. jogtar.hu/jogszabaly?docid=99100008.TV 